\title{
Mengoptimalkan Supervisi Akademik Dalam Proses Pembelajaran Di Kelas Upaya Meningkatkan Kompetensi Guru TK PGRI 4 Mataram Semester Dua Tahun Pelajaran 2018/2019
}

\author{
Sri Handayani \\ Kepala TK PGRI 4 Mataram
}

\begin{abstract}
Abstrak. Yang melatar belakangi diadakannya Penelitian Tindakan Sekolah (PTS) ini yaitu rendahnya kompetensi Guru dalam proses pembelajaran di kelas. Solusinya yaitu dengan mengefektifkan pelaksanaan supervisi akademik. Permasalahannya apakah pelaksanaan supervisi akademik dapat meningkatkan kompetensi guru dalam proses pembelajaran di kelas semester dua Tahun pelajaran 2018/2019 di TK PGRI 4 Mataram. Tujuan penelitian ini adalah untuk mengetahui efektifitas pelaksanaan supervisi akademik dalam upaya meningkatkan kompetensi Guru dalam pembelajaran di kelas, yang manfaatnya bagi kepala sekolah adalah untuk mengetahui peningkatan kompetensi guru dalam proses pembelajaran. Penelitian ini dilaksanakan selama dua siklus, masingmasing siklus kegiatannya ada empat tahapan yaitu perencanaan, pelaksanaan, observasi, dan refleksi. Indikator keberhasilan dalam penelitian ini adalah; 1) hasil observasi kepala Sekolah maupun observasi guru selama proses pendampingan telah memperoleh skor rata-rata $\geq 4,0,2$ ) hasil akhir $>85 \%$ dari jumlah peserta pendampingan memperoleh nilai rata-rata $\geq 75,00$ (kategori baik). Hasil penelitian pada siklus I observasi Kepala Sekolah rata-rata $(3,40)$, observasi guru rata-rata $(3,25)$ dan hasil supervisi akademik guru kelas rata-rata nilai $(64,92)$. Pada siklus II observasi kepala Sekolah rata-rata $(4,60)$ dengan prosentase ketercapaian $(100 \%)$, observasi guru rata-rata $(4,75)$ dengan prosentase ketercapaian $(100 \%)$ dan hasil supervisi akademik di sasaran (guru bahasa inggris) rata-rata nilai $(86,50)$ dengan prosentase ketercapaian $(100 \%)$. Indikator keberhasilan telah tercapai, penelitian di nyatakan berhasil dan dihentikan pada siklus II. Kesimpulan; Hasil penelitian pada siklus ke 2 menunjukkan peningkatan kompetensi Guru dalam proses pembelajaran di kelas senyatanya. Disarankan agar Kepala Sekolah lainnya melakukan penelitian sejenis dalam upaya peningkatan kompetensi guru, dan kepada guru kelas sejenis agar melakukan proses pembelajaran sesuai dengan skenario yang telah direncanakan dengan baik, tanggung jawab, bersunggungsungguh demi peningkatan prestasi belajar peserta didik sesuai dengan bidang studi/mata pelajaran yang menjadi tanggung jawabnya.
\end{abstract}

Kata kunci : Supervisi akademis - kompeten

\section{PENDAHULUAN}

\section{Latar Belakang}

Dalam konteks ini seorang guru TK dituntut untuk bisa membelajarkan peserta didik dengan bermain sambil belajar atau kebalikannya belajar sambil bermain. Bermain sambil belajar merupakan kebalikan dari belajar sambil bermain. Jika belajar sambil bermain lebih menekankan pada pelajarannya, maka bermain sambil belajar lebih menekankan pada jenis permainannya. Oleh sebab itu seorang pendidik perlu memahami karakteristik anak untuk mengoptimalkan kegiatan pembelajaran. Guru/pendidik dapat memberikan materi pembelajaran sesuai dengan perkembangan anak. Bagi guru TK konsep dasar pembelajaran pada dasarnya adalah salah satu rangkaian dengan konsep belajar dan mengajar. Pada prinsipnya mengajar adalah proses yang terjadi pada guru bagaimana menyampaikan materi pelajaran pada anak didiknya. Mengajar adalah seni untuk mentransfer pengetahuan, ketrampilan, dan nilai-nilai yang diarahkan oleh nilai-nilai pendidikan, kebutuhan anak.

Di TK PGRI 4 Mataram guru gurunya sudah mencoba untuk menerapkan model pembelajaran yang memihak pada pembelajaran peserta didik aktif, berupaya untuk bersikap sabar, lemah lembut, penuh pengertian dan selalu bersuka ria. Akan tetapi 
masih juga guru suka marah-marah, berkata dengan nada keras kepada peserta didik. Ada juga guru yang masih acuh tak acuh, malas, kurang peduli kepada peserta didik dan perilaku lain yang kurang terpuji.

Rendahnya kompetensi guru TK PGRI 4 Mataram dalam proses pembelajaran di kelas senyatanya disebabkan oleh beberapa factor yaitu: 1) hamper semua guru belum pernah mengikuti pendidikan dan pelatihan (Diklaat) yang materinya khusus masalah proses pembelajaran di kelas, 2) kegiatan Kelompok Kerja Guru (KKG) di TK PGRI 4 Mataram tidak berjalan, begitu juga KKG tingkat kecamatan maupun tingkat kota kurang berjalan, dan 3) latar belakang ijazah semua guru hanya sarjana umum, bukan sarjana khusus jurusan guru $\mathrm{TK}$, ada juga yang masih lulusan D2 dengan titel A.Ma.

Ada beberapa solusi yang dapat dilakukan oleh kepala TK PGRI 4 Mataram selaku peneliti, diantaranya adalah mengoptimalkan supervisi akademik dalam proses pembelajaran. Adapaun pelaksanaaan supervisi dalam proses pembelajaran ini dikombinasi dengan Penelitian Tindakan Sekolah (PTS). Mengoptimalkan supervisi akademik dalam proses pembelajaran ini sangat efektif dalam upaya meningkatkan kompetensi guru TK PGRI 4 Mataram ketika sedang melaksanakan tugas dan tanggung jawabnya sebagai pendidik di jenjang Taman Kanak-kanak (TK), karena memiliki beberapa keunggulan; 1) dapat meningkatkan kompetensi guru TK dalam proses pembelajaran khususnya ketika guru sedang menerapkan pendekatan, strategi, model, dan metode yang tepat sesuai dengan tingkat usia TK, 2) guru mampu menciptakan suasana pembelajaran yang selalu bergembira, mampu menyemangati peserta didik untuk berkreassi, berkolaborasi, dan menanamkan rassa kesetiakawanan sosial terhadap sesama peserta didik, dan 3) guru mampu membuat suasana belajar yang enjoy, rileks, tetapi tepat sasaran dan peserta didik bisa menemukan jati dirinya melalui belajar bersama-sama dengan teman sejawatnya.

Untuk membuktikan beberapa keunggulan dengan mengoptimalkan pelaksanaan supervisi akademik dalam proses pembelajaran, perlu diadakan Penelitian Tindakan Sekolah (PTS) dengan judul "Mengoptimalkan Supervisi Akademik Dalam Proses Pembelajaran Di Kelas Upaya Meningkatkan Kompetensi Guru TK PGRI 4 Mataram Semester Dua Tahun Pelajaran 2018/2019"

\section{Rumusan Masalah}

"bagaimana melaksanakan supervisi akademik dalam proses pembelajaran di kelas upaya meningkatkan kompetensi guru TK PGRI 4 Mataram semester dua Tahun pelajaran 2018/2019?".

\section{Tujuan Penelitian}

untuk mengetahui efektifitas pelaksanaan pembimbingan dengan mengoptimalkan supervisi akademik di kelass bagi guru TK PGRI 4 Mataram semester dua tahun pelajaran 2018/2019.

\section{Manfaat Penelitian}

- Manfaat bagi kepala TK PGRI Mataram/selaku peneliti

sangat bermanfaat dalam rangka melaksanakan pembimbingan bagi guru kelas di sekolah binaannya khususnya tentang tata cara mengajar yang baik dan benar melalui kegiatan supervisi akademik.

- Manfaat bagi guru TK PGRI 4 Mataram sangat bermanfaat dalam upaya meningkatkan kompetensi dalam proses pembelajaran di kelas senyatanya sehingga bisa menjadi guru yang profesional dan mampu mengajar peserta didik dengan skenario yang telah ditetapkan pada Rencana Pelaksanaan Pembelajaran Harian (RPPH).

\section{KAJIAN PUSTAKA \\ Kerangka Teoritis \\ SUPERVISI AKADEMIK}

Salah satu tugas Kepala sekolah/madrasah adalah melaksanakan supervisi akademik. Untuk melaksanakan supervisi akademik secara efektif diperlukan keterampilan konseptual, interpersonal dan teknikal (Glickman, at al. 2007). Oleh sebab itu, setiap Kepala sekolah/madrasah harus memiliki dan menguasai konsep supervisi akademik yang meliputi: pengertian, tujuan dan fungsi, prinsip-prinsip, dan dimensidimensi substansi supervisi akademik. Supervisi akademik yang dilakukan Kepala 
sekolah/madrasah antara lain adalah sebagai berikut: (1) Memahami konsep, prinsip, teori dasar, karakteristik, dan kecenderungan perkembangan tiap bidang pengembangan pembelajaran kreatif, inovatif, pemecahan masalah, berpikir kritis dan naluri kewirausahaan, (2) Membimbing guru dalam menyusun silabus tiap bidang pengembangan di sekolah/madrasah atau mata pelajaran di sekolah/madrasah berlandaskan standar isi, standar kompetensi dan kompetensi dasar, dan prinsip-prinsip pengembangan KTSP, (3) Membimbing guru dalam memilih dan menggunakan strategi/ metode/teknik pembelajaran/bimbingan yang dapat mengembangkan berbagai potensi siswa, (4) Membimbing guru dalam melaksanakan kegiatan pembelajaran/ bimbingan (di kelas, laboratorium, dan/atau di lapangan) untuk mengembangkan potensi siswa, (5) Membimbing guru dalam mengelola, merawat, mengembangkan dan menggunakan media pendidikan dan fasilitas pembelajaran, (6) Memotivasi guru untuk memanfaatkan teknologi informasi untuk pembelajaran.

$$
\text { Kompetensi supervisi akademik }
$$
intinya adalah membina guru dalam meningkatkan mutu proses pembelajaran. Sasaran supervisi akademik adalah guru dalam melaksanakan proses pembelajaran, yang terdiri dari materi pokok dalam proses pembelajaran, penyusunan silabus dan RPP, pemilihan strategi/metode/teknik pembelajaran, penggunaan media dan teknologi informasi dalam pembelajaran, menilai proses dan hasil pembelajaran serta penelitian tindakan kelas. Oleh karena itu, materi ini diharapkan dapat memberikan wawasan kepada Kepala Sekolah dalam meningkatkan kompetensi supervisi akademik yang meliputi: (1) memahami konsep supervisi akademik, (2) membuat rencana program supervisi akademik, (3) menerapkan teknik-teknik supervisi akademik, menerapkan supervisi klinis, dan (5) melaksanakan tindak lanjut supervisi akademik.

Manfaat perencanaan program supervisi akademik adalah sebagai berikut: (1) Sebagai pedoman pelaksanaan dan Kepalaan akademik, (2) Untuk menyamakan persepsi seluruh warga sekolah tentang program supervisi akademik, (3) Penjamin penghematan serta keefektifan penggunaan sumber daya sekolah (tenaga, waktu dan biaya). Prinsip-prinsip perencanaan program supervisi akademik adalah: (1) objektif (data apa adanya), (2) bertanggung jawab, (3) berkelanjutan, (4) didasarkan pada Standar Nasional Pendidikan, dan (5) didasarkan pada kebutuhan dan kondisi sekolah/madrasah.

Sasaran utama supervisi akademik adalah kemampuan-kemampuan guru dalam merencanakan kegiatan pembelajaran, melaksanakan kegiatan pembelajaran, menilai hasil pembelajaran, memanfaatkan hasil penilaian untuk peningkatan layanan pembelajaran, menciptakan lingkungan belajar yang menyenangkan, memanfaatkan sumber belajar yang tersedia, dan mengembangkan interaksi pembelajaran (strategi, metode, teknik) yang tepat. Supervisi edukatif juga harus didukung oleh instrumen-instrumen yang sesuai.Seorang Kepala sekolah/madrasah yang akan melaksanakan kegiatan supervisi harus menyiapkan perlengkapan supervisi, instrumen, sesuai dengan tujuan, sasaran, objek metode, teknik dan pendekatan yang direncanakan, dan instrumen yang sesuai, berupa format-format supervisi.

Satu di antara tugas Kepala sekolah adalah melaksanakan supervisi akademik. Untuk melaksanakan supervisi akademik secara efektif diperlukan keterampilan konseptual, interpersonal dan teknikal (Glickman, at al. 2007). Oleh sebab itu, setiap Kepala sekolah harus memiliki keterampilan teknikal berupa kemampuan menerapkan teknik-teknik supervisi yang tepat dalam melaksanakan supervisi akademik. Teknik-teknik supervisi akademik meliputi dua macam, yaitu: individual dan kelompok (Gwyn, 1961).

Teknik supervisi akademik ada dua yaitu: individual dan kelompok.

\section{SUPERVISI KELAS}

Dalam organisasi pendidikan ( dalam hal ini sistem sekolah), supervisi kelas mengacu kepada misi utama pembelajaran, yaitu kegiatan yang di tujukan untuk 
memperbaiki dan meningkatkan mutu proses dan prestasi akademik. Dengan kata lain supervisi kelas adalah kegiatan pokok yang di lakukan oleh kepala sekolah dalam pengembangan situasi belajar mengajar agar memperoleh kondisi yang lebih baik , meskipun tujuan akhirnya tertuju pada hasil belajar siswa. Supervisi kelas yakni kegiatan yang berurusan dengan perbaikan dan peningkatan proses dan hasil pembelajaran di sekolah. Dalam konteks profesi pendidikan, khususnya profesi mengajar, mutu pembelajaran merupakan refleksi dari kemampuan profesional guru. Karena itu, supervisi kelas berkepentingan dengan upaya peningkatan kemampuan profesional guru yang berdampak terhadap peningkatan mutu proses dan hasil pembelajaran. Dengan demikian fungsi supervisi kelas adalah salah satu mekanisme untuk meningkatkan kemampuan profesional guru dalam upaya mewujudkan proses belajar peserta didik yang lebih baik, melalui cara mengajar yang lebih baik pula. Dalam analisis terakhir, keefektifan supervisi kelas indikatornya adalah peningkatan hasil belajar peserta didik.

Tujuan supervisi kelas ialah memperkembangkan situasi belajar dan mengajar yang lebih baik. Usaha ke arah perbaikan belajar dan mengajar ditujukan kepada pencapaian tujuan akhir dari pendidikan yaitu pembentukan pribadi anak secara maksimal.

Tujuan umum supervisi pendidikan harus sama dengan Tujuan Pendidikan Nasional sesuai keputusan MPR yang tertera dalam GBHN, melalui perbaikan serta peningkatan kegiatan belajar mengajar.

Situasi belajar mengajar di sekolahsekolah sekarang ini menggambarkan suatu keadaan yang sangat kompleks. Kekalutan yang ada adalah akibat faktor-faktor obyektif yang saling mempengaruhi sehingga mengakibatkan menurunnya hasil belajar. Karena itu perlu menciptakan situasi yang memungkinkan murid-murid dapat belajar dengan baik dan guru-guru dapat membimbing dalam suasana kreatif dimana mereka merasa bertumbuh dalam jabatan mengajar mereka.

PROSES PEMBELAJARAN
Pengertian proses pembelajaran adalah proses interaksi peserta didik dengan pendidik dan sumber belajar pada suatu lingkungan belajar. Pembelajaran merupakan bantuan yang diberikan pendidik agar dapat terjadi proses pemerolehan ilmu dan pengetahuan, penguasaan kemahiran dan tabiat, serta pembentukan sikap dan kepercayaan pada peserta didik. Dengan kata lain, pembelajaran adalah proses untuk membantu peserta didik agar dapat belajar dengan baik. Pembelajaran mempunyai pengertian yang mirip dengan pengajaran, walaupun mempunyai konotasi yang berbeda. Dalam konteks pendidikan, guru mengajar supaya peserta didik dapat belajar dan menguasai isi pelajaran hingga mencapai sesuatu obyektif yang ditentukan (aspek kognitif), juga dapat mempengaruhi perubahan sikap (aspek afektif), serta ketrampilan (aspek psikomotor) seseorang peserta didik.

Pembelajaran biasanya terjadi dalam situasi formal yang secara sengaja diprogramkan oleh guru dalam usahanya mentransformasikan ilmu kepada peserta didik, berdasarkan kurikulum dan tujuan yang hendak dicapai. Melalui pembelajaran peserta didik melakukan proses belajar sesuai dengan rencana pengajaran yang telah diprogramkan. Dengan demikian, unsur kesengajaan melalui perencanaan oleh pihak guru merupakan ciri utama pembelajaran. Upaya pembelajaran yang berakar pada pihak guru dilaksanakan secara sistematis yaitu dilakukan dengan langkah-langkah teratur dan terarah secara sistematik. yaitu secara utuh dengan memperhatikan berbagai aspek. Maka konsep belajar dan pembelajaran merupakan dua kegiatan yang berproses dalam suatu sistem.

Jadi, dapat disimpulkan bahwa fungsi pembelajaran secara umum adalah merangsang dan menyukseskan proses belajar dan untuk mencapai tujuan, Sedangkan fungsi belajar adalah dapat memanfaatkan semaksimal mungkin sumber belajar untuk mencapai tujuan belajar, yaitu terjadinya perubahan dalam diri peserta didik. Untuk memberikan gambaran yang lebih jelas mengenai konsep belajar dan mengajar (pembelajaran), berikut dipaparkan kedua konsep itu. 


\section{KOMPETENSI GURU}

Untuk memberikan pengertian dan pemahaman tentang kompetensi guru, akan diuraikan terlebih dahulu pengertian kompetensi secara umum. Kompetensi berasal dari kata competency yang berarti yang berarti kemampuan atau kecakapan. Menurut kamus besar Bahasa Indonesia, kompetensi dapat diartikan (kewenangan) kekuasaan untuk menentukan atau memutuskan satu hal. Istilah kompetensi memiliki banyak makna dan pengertian diantaranya adalah sebagai berikut: Menurut Mulyasa (2007) kompetensi merupakan perpaduan dari pengetahuan, nilai dan sikap yang direfleksikan dalam kebebasan berfikir dan bertindak. Boyatzis (2008) dalam Cahyo Wirawan (2012) mengemukakan kompetensi merupakan karakteristikkarakteristik dasar seseorang yang menuntun dan menyebabkan keefektifan dan kinerja yang menonjol. Sedangkan menurut Antariksa (2007) dalam Cahyo Wirawan (2012) kompetensi sendiri dapat dipahami sebagai sebuah kombinasi antara ketrampilan (skiil), akibat personal, dan pengetahuan yang tercermin melalui perilaku kinerja yang dapat diamati, di ukur dan dievaluasi.

Kompetensi guru mengandung arti kemampuan seorang guru dalam melaksanakan kewajiban, tugas, tanggung jawab serta peranannya secara layak dan profesional sesuai standar yang ditetapkan dalam profesi guru (Usman, 2005). Kompetensi guru terdiri dari empat kompetnsi utama yaitu kompetensi pedagogik, kompetensi sosial, kompetensi akademik, dan kompetnsi kepribadian. Guru yang memiliki keempat kompetensi itu secara maksimal akan lebih mampu mengelola kelasnya sehingga belajar para siswa berada pada tingkat optimal (Hamatih, 2006). Dimana kompetensi yang harus dimiliki sesorang agar mampu bekerja optimal meliputi tiga dimensi, yaitu: 1) kompetensi kognitif, 2) kompetensi kecerdasan, dan 3) kompetensi psikomotorik. (Darnali, 2010).

Yang dimaksud kompetensi guru dalam penelitian ini adalah kemampuan dan ketrampilan ke 4 (empat) guru kelas TK PGRI 4 Mataram dalam proses pembelajaran di kelas senyatanya. Kompetensi yang dimaksud adalah kemampuan dan ketrampilan dalam menerapkan pendekatan, strategi, dan metode pembelajaran sesuai dengan Rencana Pelaksanaan Pembelajaran (RPP) yang telah di siapkan.

KKG

Trimo (2007: 12) Kelompok Kerja Guru yaitu suatu organisasi profesi guru yang bersifat struktural yang dibentuk oleh guruguru di suatu wilayah atau gugus sekolah sebagai wahana untuk saling bertukaran pengalaman guna meningkatkan kemampuan guru dan memperbaiki kualitas pembelajaran. Melalui KKG guru memiliki kesempatan dan berpotensi mendiskusikan penyelesaian permasalahan yang dihadapi di kelas. Trimo (2007: 12) menyatakan, "pembinaan melalui KKG memberikan kesempatan bagi guru yang lebih luas (dimungkinkan semua guru terlibat), dibanding bentuk pembinaan yang lain (harus menunggu kesempatan)". Uceh Nurabnu (2012: 24) Gugus TK merupakan wadah kegiatan Kelompok Kerja Guru (KKG) dan Kelompok Kerja Kepala TK (KKKTK) yang telah ditetapkan melalui Direktur Jendral Pendidikan Dasar dan Menengah, Departemen Pendidikan dan Kebudayaan Nomor 086/c/Kep/v/tanggal 8 Mei 1995.

$$
\text { Standar pengembangan KKG }
$$

Derektorat Profesi Pendidik Direktorat Jendral Peningkatan Mutu Pendidikan dan Tenaga Kependidikan Departemen Pendidikan dan Kebudayaan Republik Indonesia menyatakan bahwa KKG merupakan wadah atau forum kegiatan profesional bagi para guru Sekolah Dasar/Madrasah Ibtidaiyah di tingkat gugus atau kecamatan yang terdiri dari beberapa guru dari berbagai sekolah".

Yang dimaksud dengan kelompok kerja guru (KKG) dalam penelitian ini adalah 4 (empat) guru TK PGRI 4 Mataram yang menjadi sasaran dalam pelaksanaan pendampingan dalam supervisi akademik. Kegiatan nyata KKG TK PGRI 4 Mataram yaitu pelaksanaan supervisi yang dibimbing langsung oleh kepala sekolah selaku peneliti. Dalam kegiatan ini semua guru kelas dari kelas A dan kelas disupervisi secara individual dalam forum KKG. Kendala/kesulitan yang dialami oleh guru 
langsung diberikan bimbingan, perbaikan, dan penyempurnaan sesuai dengan situasi dan kondisi pada saat KKG yang diselenggarakan di TK PGRI 4 Mataram.

\section{PENDAMPINGAN/PEMBIMBINGAN}

Pendampingan adalah Upaya terus menerus dan sistematis dalam mendampingi (menfasilitasi) individu, kelompok maupun komunitas dalam mengatasi permasalahan dan menyesuaikan diri dengan kesulitan hidup yang dialami sehingga mereka dapat mengatasi permasalahan tersebut dan mencapai perubahan hidup ke arah yang lebih baik. (Yayasan Pulih, 2011). Pendampingan merupakan proses interaksi timbal balik (tidak satu arah) antara individu/ kelompok/komunitas yang mendampingi dan individu/kelompok/komunitas yang didampingi yang bertujuan memotivasi dan mengorganisir individu/kelompok/komunitas dalam mengembangkan sumber daya dan potensi orang yang didampingi dan tidak menimbulkan ketergantungan terhadap orang yang mendampingi (mendorong kemandirian). (Yayasan Pulih, 2011). Pendampingan dapat dilakukan dalam berbagai bentuk maupun situasi dengan pendekatan yang beragam baik formal maupun non formal, individu, kelompok maupun komunitas.

Yang dimaksud dengan pendampingan dalam penelitian tindakan sekolah (PTS) ini adalah kepala TK PGRI 4 Mataram selaku peneliti membimbing/mendampingi terhadap 4 (empat) guru sasaran dalam kegiatan supervisi akademik. Dalam pelaksanaannya pendampingan dilakukan melalui 2 (dua) tahapan. Tahap I semua guru dikumpulkan untuk mendapatkan penjelasan teknik tata cara mengajar yang baik dan benar. Tahap II yaitu pendampingan individual, dimana peneliti mendampingi secara bergiliran diwaktu yang berlainan.

\section{Hipotesis Tindakan}

"pelaksanaan supervisi akademik dapat meningkatkan kompetensi guru kelas TK PGRI 4 Mataram dalam proses pembelajaran di kelas semester dua Tahun pelajaran 2018/2019"

\section{METODE PENELITIAN}

\section{Jenis Penelitian}

\section{Setting Penelitian}

Penelitian Tindakan Sekolah (PTS) ini dilaksanakan di TK PGRI 4 Mataram dengan mengefektifkan pelaksanaan supervisi akademik bagi enam orang guru kelas.

\section{Perencanaan Tindakan}

\section{Jenis tindakan yang dilakukan}

- Kepala Sekolah menyampaikan hasil pemantauan terhadap 4 (empat) guru kelas dalam proses pembelajaran di kelas ditemukan masih mengalami kendala.

- Kepala Sekolah menyampaikan materi pendampingan yang terfokus pada tata cara mengajar yang baik dan benar sesuai kurikulum yang berlaku.

\section{Skenario Supervisi Akademik}

Untuk mendapatkan gambaran yang jelas tentang skenario pelaksanaan tindakan dalam kegiatan supervisi akademik ini dapat digambarkan sebagai berikut:

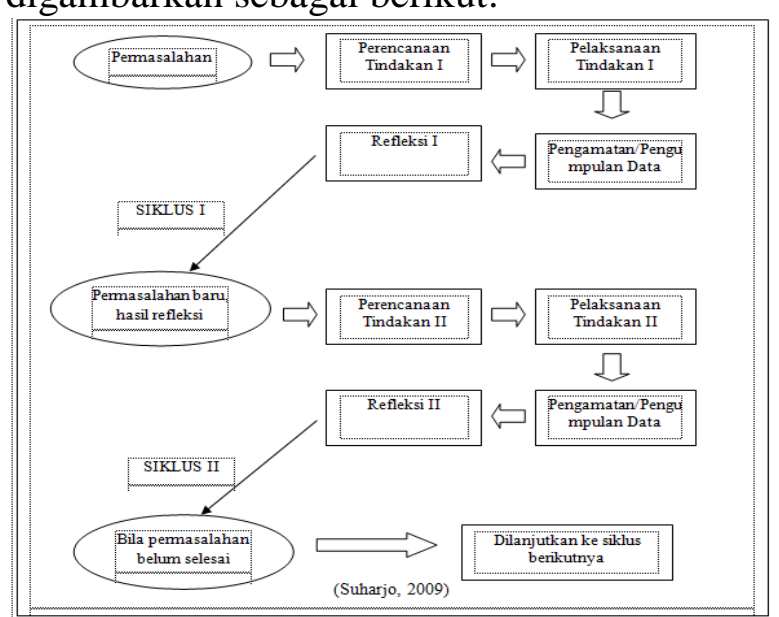

Pelaksanaan Tindakan

Pelaksanaan tindakan yang meliputi diskripsi tindakan yang akan dilakukan meliputi pelaksanaan rencana tindakan yang telah disiapkan, termasuk didalamnya langkah-langkah pelaksanaan atau praktik tetap di sekolah dalam siklus (Suharjono, 2009). Dalam penelitian ini peneliti melakukan supervisi akademik yang terfokus pada pelaksanaan proses pembelajaran di kelas senyatanya.

\section{Evaluasi dan Refleksi Tindakan}

Tahapan ini adalah melakukan kajian dan penilaian proses tindakan dan hasil atau dampak tindakan terhadap perilaku sasaran (Nana Sudjana, 2009; 39). Adapun kegiatan riilnya adalah : 1) membandingkan hasil 
pengamatan aktifitas dari ke 4 (empat) guru kelas selama proses bimbingan selama supervisi akademik, 2) membandingkan perolehan nilai hasil kegiatan pembelajaran di kelas senyatanya dengan indikator keberhasilan yang telah ditetapkan.

\section{SIKLUS TINDAKAN}

SIKLUS I

\section{Tahap I : Perencanaan Tindakan}

1. Menyusun materi tentang supervisi akademik

2. Menetapkan skneario dan langkah-langkah pendampingan

3. Menyusun instrumen observasi Kepala sekolah dan observasi guru

4. Menentukan jadwal kegiatan supervisi akademik

5. Menyusun pedoman analisa data hasil observasi dan hasil supervisi akademik

Tahap II : Pelaksanaan Tindakan

a) Kegiatan pendampingan

1. Menyampaikan materi tentang tata cara mengajar yang baik dan benar

2. Melaksanakan tanya jawab tentang tata cara mengajar yang baik dan benar

3. Memberikan bimbingan terhadap peserta yang mengalami kesulitan

4. Memberikan solusi terhadap permasalahan yang dihadapi guru

5. Memberikan penguatan/reward

6. Memberikan tugas individual

b) Kegiatan supervisi akademik

Secara terjadwal dan bergiliran peneliti melakukan supervisi akademik di kelas tempat guru mengajar

Tahap III : Pengamatan/pengumpulan Data

1. Pengamatan terhadap aktifitas guru selama pembimbingan

2. Pengamatan terhadap guru dalam proses pembelajaran (supervisi akademik)

3. Menilai hasil tampilan guru selama proses pembelajaran di kelas

\section{Tahap IV : Refleksi}

1. Renungan atas data hasil observasi dan hasil penilaian selama proses pembelajaran di kelas
2. Pengolahan data hasil penelitian dan mencocokkan dengan indikator keberhasilan

3. Rencana perbaikan dan penyempurnaan

4. Memberikan penguatan atas hasil yang diperolehnya.

5. Rencana tindak lanjut

SIKLUS II

Jenis kegiatan pada siklus II ini pada dasarnya sama dengan siklus I, bedanya hanya terjadi perbaikan/penyempurnaan

dalam pelaksanaannya.

\section{Indikator Keberhasilan}

1. Hasil observasi Kepala sekolah maupun observasi guru selama proses pendampingan telah memperoleh skor rata-rata $\geq 4,0$ (kategori baik/kategori aktif)

2. Kompetensi pedagogik dalam proses pembelajaran dinyatakan berhasil jika $\geq$ $85 \%$ dari jumlah guru kelas memperoleh nilai rata-rata $\geq 75,00$ (kategori baik).

\section{HASIL DAN PEMBAHASAN \\ Laporan Hasil \\ SIKLUS I}

Tahap Perencanaan

Pada tahapan ini peneliti telah berhasil: 1) menyusun materi tentang supervisi akademik, 2) menetapkan skenario dan langkah-langkah pendampingan, 3) menyusun instrumen observasi Kepala sekolah observasi guru, dan instrumen kegiatan supervisi akademik, 4) menentukan jadwal kegiatan supervisi akademik yang terbagi menjadi 2 (dua) pertemuan, 5) menyusun pedoman analisa data hasil observasi dan hasil supervisi akademik,

\section{Tahap Pelaksanaan}

Pada tahapan ini peneliti melakukan 2 (dua) kegiatan yaitu kegiatan pendampingan/pembimbingan secara klasikal, dan kegiatan kedua adalah pelaksanaan supervisi akademik di kelas senyatanya.

\section{Tahap Pengumpulan/Pengumpulan Data}

Hasil Observasi Kepala Sekolah memperoleh skor rata-rata sebesar 3,40, observasi guru memperoleh memperoleh skor rata-rata sebesar 3,25, hasil Supervisi Akademik Di Kelas memperoleh nilai rata-rata sebesar 64,92 . 


\section{Tahap Refleksi}

Pada tahap ini peneliti melakukan beberapa kegiatan yang merupakan tahapan akhir dari pelaksanaan siklus I, yaitu kegiatan perencanaan, pelaksanaan, dan observasi. Adapun kegiatan secara rinci meliputi: 1) renungan atas data hasil observasi dan hasil pengamatan selama proses pembelajaran di kelas senyatanya, 2) pengolahan data hasil penelitian dan mencocokkan dengan indikator keberhasilan, 3) rencana perbaikan dan penyempurnaan, 4) memberikan penguatan atas hasil yang diperolehnya, dan 5) rencana tindak lanjut.

\section{SIKLUS II}

\section{Tahap Perencanaan}

Pada tahapan ini peneliti kegiatannya masih mengacu pada siklus I yakni merencanakan: 1) penyusunan materi tentang supervisi akademik, 2) menetapkan skenario dan langkah-langkah pendampingan, 3) menyusun instrumen observasi Kepala sekolah dan observasi guru, 4) menentukan jadwal kegiatan supervisi akademik, 5) menyusun pedoman analisa data hasil observasi dan hasil supervisi akademik.

\section{Tahap Pelaksanaan}

Pada tahapan ini peneliti kegiatannya adalah masih sama dengan siklus I, bedanya pada siklus II ini pelaksanaannya lebih dioptimalkan karena kesalahan-kesalahan dan kekurangan pada siklus I sudah di deteksi dan sudah dicari jalan keluarnya.

\section{Tahap Pengamatan/Pengumpulan Data}

Hasil Observasi Kepala Sekolah memperoleh skor rata-rata sebesar 4,60, observasi guru memperoleh memperoleh skor rata-rata sebesar 4,70, hasil Supervisi Akademik Di Kelas memperoleh nilai rata-rata sebesar 86,50.

\section{Tahap Refleksi}

Pada tahapan ini peneliti melakukan kegiatan penyempurnaan terhadap kesalahankesalahan yang terjadi pada siklus I. Adapum untuk kegiatannya adalah: 1) renungan atas data hasil observasi Kepala sekolah dan guru serta hasil supervisi akademik di kelas, 2) pengolahan data hasil penelitian dan mencocokkan dengan indikator kinerja, 3) rencana perbaikan dan penyempurnaan, 4) memberikan penguatan atas hasil yang diperolehnya, dan 5) rencana tindak lanjut.

\section{Pembahasan}

\section{SIKLUS I}

\section{Tahap Perencanaan}

Ada beberapa kendala yang dihadapi dalam proses perencanaan pada penelitian ini diantaranya dalam penyusunan materi tentang supervisi akademik, persiapan skenario tindakan selama pendampingan, penyusunan instrumen observasi Kepala sekolah dan instrumen observasi peserta pendampingan, penentuan jadwal supervisi akademik bagi 6 (enam) guru kelas dalam proses pembelajaran di kelas, dan menentukan penyusunan pedoman analisa data hasil observasi Kepala sekolah, observasi guru dalam proses pembelajaran. Setelah berkonsultasi kepada pembimbing kendala yang dihadapi dapat diatasi dan kegiatan dapat berjalan dengan baik lancar.

\section{Tahap Pelaksanaan}

Dalam melaksanakan pendampingan klasikal tentang perlunya pendampingan dan penyampaian materi tentang supervisi akademik yang kegiatan nyatanya menjelaskan bagaimana cara mengajar yang baik dan benar sesuai dengan instrumen yang telah ditetapkan, serta pelaksanaan tanya jawab kepada peserta mengalami hambatan yaitu yang seharusnya pukul 08.00 dimulai tetapi karena sebagian guru ada yang masih ada yang mengajar, ada yang memberikan tugas kepada peserta didik yang berakibat molornya pelaksanaan pendampingan klasikal. Solusinya peneliti mengundurkan waktu pelaksanaan +15 menit, setelah semua guru berkumpul baru dilaksanakan pendampingan klasikal. Hasilnya semua rencana dapat terlaksana tanpa menambah waktu yang telah disiapkan.

\section{Tahap Pengamatan/Pengumpulan Data}

Hasil skor rata-rata yang diraih oleh Kepala sekolah/peneliti $(3,40)$ kategori cukup dari indikator keberhasilan yang diharapkan yaitu $\geq 4,00$ (kategori aktif). Sementara itu hasil observasi guru oleh peneliti selama proses pendampingan klasikal, dilihat dari aktifitas dari ke enam guru kelas memperoleh rata-rata $(3,25)$ kategori cukup dari indikator keberhasilan yang direncanakan yaitu $>4,00$ 
(kategori aktif). Perolehan nilai rata-rata hasil supervisi akademik dari 4 (empat) guru kelas diperoleh hasil $(64,92)$ dengan presentase ketuntasan $0 \%$, 3) peneliti mengadakan perbaikan/penyempurnaan berupa bimbingan individual dan bimbingan secara klasikal.

\section{Tahap Refleksi}

Setelah semua perolehan data dianalisis dan di cocokkan dengan indikator keberhasilan, diperoleh data sebagai berikut: Hasil Observasi Kepala Sekolah $(3,40)$, Hasil Observasi Guru $(3,25)$, dan Hasil Supervisi Akademik $(64,92)$

\section{SIKLUS II}

\section{Tahap Perencanaan}

Pada tahapan ini peneliti telah memperbaiki semua kekurangan dan kesalahan-kesalahan yang dilakukan pada siklus I. Pada siklus II semua perencanaan tidak ada hambatan artinya berjalan sesuai dengan rencana yang telah ditetapkan. Kegiatan-kegiatan nyata yang dilakukan tidak ada hambatan adalah: 1) penyusunan materi pendampingan berkaitan dengan supervisi akademik, 2) penetapan/penyusunan skenario tindakan, 3) penyusunan instrumen observasi, 4) penentuan jadwal kegiatan, dan 5) penyusunan pedoman analisa data. Beberapa hal yang sangat berkesan pada tahapan ini antara lain; 1) peneliti bisa membuat guru kelas merasa lega dan merasakan akan manfaat supervisi akademik dalam proses pembelajaran, 2) pengawas pembimbing juga merasa puas dengan persiapan peneliti melalui kegiatan pada tahap perencanaan.

\section{Tahap Pelaksanaan}

Peneliti melakukan pendampingan klasikal dengan mengoptimalkan tindakan nyata terutama kesalahankesalahan/kekurangan yang terjadi pada siklus I lebih dioptimalkan, sehingga dalam pelaksanaan pendampingan pada siklus II ini berjalan lancar tanpa hambatan yang berarti.

\section{Tahap Pengamatan/Pengumpulan Data}

Hasil pengamatan penampilan Kepala sekolah/peneliti yang dilakukan oleh observer, maupun hasil pengamatan guru selama proses pendampingan oleh kepala sekolah diperoleh data sebagai berikut: Hasil Observasi Kepala Sekolah (4,60), Hasil
Observasi Guru (4,75). Perolehan hasil supervisi akademik pada siklus II memperoleh skor rata-rata $(85,96 /$ kategori baik) dan dinyatakan $100 \%$ tuntas. Hasil ini merupakan dampak positif dari upaya mengoptimalkan tindakan pelaksanaan supervisi akademik dikelas senyatanya.

\section{Tahap Refleksi}

Hasil observasi Kepala sekolah, guru peserta pendampingan serta hasil supervisi akademik di kelas senyatanya telah melebihi indikator keberhasilan yang telah ditetapkan. Penelitian Tindakan Sekolah (PTS) dinyatakan telah berhasil dan dihentikan pada siklus II, dengan perolehan peningkatan sebagai berikut: Hasil Observasi Kepala Sekolah $(4,60)$, Hasil Observasi Guru $(4,75)$, dan Hasil Supervisi Akademik $(85,96)$.

Peneliti

memberikan reward/penghargaan kepada semua guru peserta pendampingan atas hasil yang diraih dan mampu memperoleh nilai diatas rata-rata indikator yang telah ditetapkan. Perbaikan dan penyempurnaan kegiatan tidak perlu dilakukan karena penelitian telah berhasil mencapai indikator yang telah ditetapkan. Penelitian Tindakan Sekolah (PTS) dinyatakan "BERHASIL" dan dihentikan pada siklus II.

\section{Kesimpulan}

Supervisi akademik apabila dilaksanakan dengan baik, bersungguh-sungguh, dan bertanggung jawab akan mampu menyentuh karakter guru untuk melaksanakan proses pembelajaran yang mengarah pada kegiatan peserta didik aktif dan senantiasa berupaya meningkatkan kompetensinya dalam upaya menjadi guru yang profesional dalam bidang pembelajaran di kelas senyatanya. Data hasil penelitian menunjukkan bahwa pada siklus II mengalami peningkatan yang cukup signifikan yang dibuktikan dengan sajian data sebagai berikut:

\begin{tabular}{|c|l|c|c|c|c|}
\hline \multirow{2}{*}{ No } & \multicolumn{2}{|c|}{ Jenis Kegiatan } & \multirow{2}{*}{$\begin{array}{c}\text { Indikator } \\
\text { Keberhasilan }\end{array}$} & Perolehan & \multicolumn{2}{|c|}{ Keterangan } \\
\cline { 4 - 6 } & & & Siklus I & Siklus II & \\
\hline 1. & Observasi Kepala Sekolah & $\geq 4,00$ & 3,40 & 4,60 & Tuntas \\
\hline 2. & Observasi Guru & $\geq 4,00$ & 3,25 & 4,75 & Tuntas \\
\hline 3. & $\begin{array}{l}\text { Supervisi Akademik di } \\
\text { Kelas }\end{array}$ & $\geq 70,00$ & 64,92 & 85,96 & Tuntas \\
\hline
\end{tabular}

\section{Saran}

Bagi Kepala Sekolah Sejawat Diharapkan untuk melakukan supervisi akademik 
secara efektif, karena dengan mengefektifkan supervisi akademik dapat meningkatkan kompetensi guru dalam proses pembelajaran di kelas senyatanya sesuai dengan mata pelajaran yang diajarkan dan menjadi tanggung jawabnya masing-masing.

- $\quad$ Bagi Guru kelas

a. Merencanakan kegiatan pembelajaran dengan sebaik-baiknya dengan strategi pembelajaran yang mengarah ke peserta didik aktif, kreatif, inovatif, dan demokratif.

b. Melakukan proses pembelajaran sesuai dengan skenario yang telah direncanakan dengan baik, tanggung jawab, bersunggung-sungguh demi peningkatan prestasi belajar peserta didik sesuai dengan bidang studi/mata pelajaran yang menjadi tanggung jawabnya.

\section{DAFTAR PUSTAKA}

A. alauddin, 2019. Supervisi Akademik Kepala Sekolah. https://www.academia.edu/6747/SUPE RVISI_AKADEIK_OLEH_KEPALA_ SEKOLAH. diambil tanggal 10 Januari 2019. Pukul 19.36 wita.

Alexander Mackie College of Advance Education. 1981. Supervision of Practice Teaching. Primary Program, Sydney, Australia.

Anonim, 2019, Aspek dan Kompetensi guru, dalam

https://akhmadsudrajat.wordpress.com/2 012/01/29/kompetensi-guru/, diambil tanggal 10 Januari 2019. Pukul 19.38 Wita

Anonim, 2019, Definisi Pendampingan, dalam

https://kamuspsikososial.wordpress.co m/tag/definisi-pendampingan/, diakses tanggal 15 Januari 2019 Pukul 10.45 Wita

Anonim, 2019, Pengertian Pendampingan, dalam http://www.bintans.web.id/2010/12/pengertian- pendampingan.html, diakses tanggal 20 Januari 2019 Pukul 11.04 Wita

Anonim, 2019, Pengertian proses

pembelajaran, dalam

https://www.academia.edu/7330523/P engertian_Proses_Pembelajaran?auto= download diakses tanggal 20 Januari 2019 Pukul 12.00 Wita

Anonim, 2019, Supervisi kelas, dalam https://hidayatussaadah123.blogspot.co m/2017/05/apa-itu-supervisi-kelas.html, diambil tanggal 13 Januari 2019. Pukul 09.45 Wita

Cahya Wirawan, 2012, Peningkatan Kompetensi Guru kelas Dalam Pemanfaatan Media Pembelajaran Melalui Mentoring, Jakarta: Jurnal PTK Dikmen

Dodd, W.A. 1972. Primary School Inspection in New Countries. London: Oxford University Press.

Glickman, C.D., Gordon, S.P., and RossGordon, J.M. 2007. Supervision and Instructional Leadership A Development Approach. Seventh Edition. Boston: Perason.

Gwynn, J.M. 1961. Theory and Practice of Supervision. New York: Dodd, Mead \& Company. Hamatih, 2006, Kurikulum Tingkat Satuan Pendidikan, Bandung: Remaja Rosda Karya. Irwan sahaja , 2019, Pengertian Kelompok Kerja Guru, dalam http://irwansahaja.blogspot.co.id/2014/ 08/pengertian-kelompok-kerja-gurukkg.html, diakses tanggal 20 JAnuari 2019, pukul 20.30 Wita

Mantja, W. 1984. "Efektivitas Supervisi Klinik dalam Pembimbingan Praktek Mengajar Mahasiswa IKIP Malang,"Tesis. FPS IKIP Malang.

Mulyasa, 2007, Kurikulum Tingkat Satuan Pendidikan, Bandung: Remaja Rosda Karya.

Nana Sujana, 2009, Pendidikan Tingkat KePenelitian Konsep Dan Aplikasinya Bagi Peneliti Sekolah, Jakarta: LPP Bina Mitra.

Peraturan Pemerintah Republik Indonesia Nomor 74 Tahun 2008 Tentang Guru

Robbins, S.P.2008. The Truth about Managing People. Second Edition. 
Upper Sadle River, New Jersey: Pearson Education, Inc.

Sergiovanni, T.J. 1982. Supervision of Teaching. Alexandria: Association for Supervision and Curriculum Development.

Suharjono, 2009, Melaksanakan Sekolah Sebagai Kegiatan Penelitian Tindakan Sekolah Sebagai Kegiatan Pengembangan Profesi Penelitia Sekolah, Jakarta: Bumi Aksara.

Sullivan, S \& Glanz, J. 2005. Supervision that ImprovesTeaching Strategies and Techniques. Thousand Oaks, California: Corwin Press.

Sullivan, S. \& Glanz, J. 2005. Supervision that Improving Teaching Strategies and Techniques. Thousand Oaks, California: Corwin Press.

Supervisi Akademik dalam peningkatan profesionalisme guru. 2006. Kompetensi Supervisi Kepala Sekolah Pendidikan Dasar. Direktorat Tenaga Kependidikan Ditjen PMPTK Depdiknas.

Susilawati, E., Sarnita, F., Gumilar, S., Erwinsyah, A., Utami, L., \& Amiruddin, A. (2019, November). Using inductive approach (IA) to enhance students' critical thinking (CT) skills. In Journal of Physics: Conference Series (Vol. 1280, No. 5, p. 052035). IOP Publishing.

Usman, 2005, Menjadi Guru Profesional, Bandung: Remaja Rosda Karya.

Verma, V.K. 1996. The Human Aspects of Project Management Human Resources Skills for the Project Manager. Volume Two. Harper Darby,PA: Project Management Institute

Wiles, J. dan J. Bondi. 1986. Supervision: A Guide to Practice. Second Edition. Columbus: Charles E. Merrill Publishing Company 